\title{
Sex- and Strain-dependent Effects of Bisphenol: A Consumption in Juvenile Mice
}

Brantley S Wyatt', Jessica R Gooding ${ }^{2}$, Suchita Das', Shawn R Campagna ${ }^{2}$, Arnold M Saxton', Stephen Dearth ${ }^{2}$ and Brynn H Voy ${ }^{1 *}$

${ }^{1}$ Department of Animal Science, University of Tennessee, Knoxville TN, 37996, USA

${ }^{2}$ Department of Chemistry, University of Tennessee, Knoxville TN, 37996, USA

\begin{abstract}
Children are directly exposed to bisphenol A (BPA) and other putative environmental obesogens through both diet and household products. The purpose of this study was to investigate sex- and genetic-dependent effects of BPA consumption on traits relevant to obesity and Type 2 diabetes in juveniles, using mice as models. Two strains of mice (C57BL/6J and DBA/2J) were chosen to represent distinct genetic backgrounds that differ in susceptibility to obesity and insulin resistance. Male and female mice of each strain consumed BPA at three doses in drinking water from four to eleven weeks of age. Male but not female mice of each strain consuming BPA were significantly fatter than controls. BPA induced corresponding changes in adipose tissue gene expression and metabolite abundance that indicate effects on adipogenesis and energy utilization. BPA consumption also altered the synthesis of adipokines, circulating factors that modulate insulin sensitivity and atherogenesis, in C57BL/6J but not DBA/2J males. Conversely, effects of BPA on plasma insulin were only observed in female mice, and with opposite effects in the two strains. These results suggest that dietary BPA may exacerbate childhood obesity and its consequences, and that sex and genetic background are important determinants of the physiological impact of BPA.
\end{abstract}

Keywords: Adipose; Bisphenol; Glucose; Obesity

\section{Introduction}

In recent years, the search for non-genetic contributors to the global obesity epidemic has broadened to include environmental chemicals. Data from a variety of compounds have been sufficiently compelling to prompt the term "environmental obesogen", used to refer to compounds such as endocrine disruptors that can promote an increase in fatness under certain exposure conditions [1-3]. Bisphenol $A$ is an abundant environmental endocrine disruptor and a candidate environmental obesogen [4]. Human exposure to BPA results from its widespread use to harden consumer plastics, including thermal papers, pipes, consumer plastics and many components of the commercial food and beverage stream [5-7]. As a result, approximately $93 \%$ of participants in the National Health and Nutrition Examination Survey (NHANES) who were screened for BPA exhibited detectable levels in urine [6,8]. Epidemiological studies based on NHANES as well as other populations globally link BPA exposure to risk of obesity and its consequences. Urinary level of BPA, the primary means for assessing exposure in humans, is positively associated with incidence of obesity [9-11] and with risk for insulin resistance [12-14] and cardiovascular disease [15-17] in both the U.S. and other countries.

Bisphenol A exposure is a particular concern in children, an age group with heightened sensitivity to environmental chemicals [18]. As in adults, BPA is present at measurable levels in urine from the majority of children sampled worldwide [18-21]. Urinary levels of BPA are higher in children than in adults, and in younger children compared to adolescents $[18,19,22]$. Also like adults, several studies have reported significant associations between urinary BPA and indices of obesity in juveniles. Analyses of cross-sectional data from children included in NHANES from 2003-2010 support positive relationships between urinary BPA and body mass index (BMI), waist circumference, and risk for obesity, even after adjusting for socioeconomic and lifestyle confounds [23-25]. Similar relationships were found in an independent sampling of predominantly low income Mexican-American children, even though their BPA levels were approximately half those of children in NHANES [26]. The primary source of BPA exposure in children is thought to be diet [27]. Liao et al. [28] measured BPA content in a variety of foodstuffs and then estimated that daily BPA consumption in infants, toddlers and children is more than twice that of adolescents and adults. Consumption of sodas, school lunches and meals prepared outside the home have been statistically associated with elevated urinary BPA levels [29].

Most experimental BPA studies have focused on the effects of exposure in utero or perinatally by administering BPA in the feed or drinking water of the pregnant or lactating mother. BPA was originally suggested as an obesogen by studies showing that rodents exposed to BPA in utero were heavier at birth and into adulthood [30-32]. Some, but not all, follow-on studies have linked early developmental exposure to increased fatness and to impaired glucose tolerance as adults. In utero exposure studies in rodents may be complicated by the fact that litter size, sex composition and positioning within the uterus impact the sex steroid exposure and sensitivity of each individual pup during development, which may in turn alter individual sensitivity to BPA due to its interaction with estrogen receptors [33]. Although children are predicted to consume the highest levels of BPA, and urinary levels in children have been associated with risk of obesity, relatively few experimental studies with animal models have focused on the specific effects of BPA consumption during a period comparable to childhood. Animal studies are important for filling this gap in knowledge because they allow assessment of defined consumption levels with control over external sources of exposure.

*Corresponding author: Brynn $\mathrm{H}$ Voy, Department of Animal Science, University of Tennessee, Knoxville TN, 37996, USA, Tel: (865)974-4790; E-mail: bhvoy@utk.edu

Received July 26, 2016; Accepted August 08, 2016; Published August 15, 2016

Citation: Wyatt BS, Gooding JR, Das S, Campagna SR, Saxton AM, et al. (2016) Sex- and Strain-dependent Effects of Bisphenol: A Consumption in Juvenile Mice. J Diabetes Metab 7: 694. doi: 10.4172/2155-6156.1000694

Copyright: $\odot 2016$ Wyatt BS, et al. This is an open-access article distributed under the terms of the Creative Commons Attribution License, which permits unrestricted use, distribution, and reproduction in any medium, provided the original author and source are credited. 
Risks for both obesity and type 2 diabetes are strongly influenced by genetic background in both humans and experimental models. It is therefore likely that the effects of BPA on endpoints related to these two diseases are also sensitive to genetic variation, rendering some individuals in a population more sensitive to the effects of BPA. The purpose of this study was therefore two-fold: 1.) to test the hypothesis that consumption of BPA in juveniles promotes fat accumulation and alters glucose tolerance, and 2.) to determine if these potential effects of BPA are influenced by genetic susceptibility to obesity and insulin resistance. Bisphenol A was delivered at three doses $(50 \mathrm{nM}, 500$ $\mathrm{nM}$, and $5 \mu \mathrm{M}$ ) in the drinking water of $\mathrm{C} 57 \mathrm{BL} / 6 \mathrm{~J}$ and $\mathrm{DBA} / 2 \mathrm{~J}$ mice beginning at four weeks of age, a time of active adipose accumulation but prior to sexual maturation. These two inbred strains were chosen for their differences in genetic susceptibility to obesity and insulin resistance. C57BL/6J mice are prone to diet-induced obesity and glucose intolerance, while $\mathrm{DBA} / 2 \mathrm{~J}$ are fatter at baseline but more resistant to obesogenic diets and more glucose tolerant than C57BL/6J $[33,34]$. These two strains were also chosen because they are the parental strains for a set of recombinant inbred lines [35] that could be useful for mapping genetic modifiers of BPA sensitivity, if implicated in our study. Males and females of each strain were included to evaluate sex-specific effects of BPA consumption, which have been reported in both humans and animal models. We report that consumption of BPA during a four-week window in growing mice altered both adiposity and glucose homeostasis in a strain-and sex-dependent manner.

\section{Experimental (Materials and Methods)}

\section{Animals}

All protocols were approved by the Institutional Animal Care and Use Committee at the University of Tennessee, Knoxville. Male and female C57BL/6J and DBA/2J mice to be used as breeders were obtained from The Jackson Laboratory (Bar Harbor, ME). Ten females and three males of each strain were used to produce the 64 (32 males and 32 females) pups of each strain, selected from nine litters per strain, used in this study. Pups were weaned at 23 days of age and randomized to a treatment group to avoid litter effects. Mice were housed in BPA-free polypropylene cages, and water was provided in glass bottles to limit exposure to BPA or other estrogenic compounds from the environment. Beginning at four weeks of age and continuing until 11 weeks of age, BPA was administered to the mice via drinking water, which was available ad libitum, at concentrations of $50 \mathrm{nM}$, $500 \mathrm{nM}$, or $5 \mu \mathrm{M}$. Bisphenol A (Sigma-Aldrich, St. Louis, MO) was dissolved in a glass vial using ethanol distilled in glass tubing to minimize exogenous BPA from commercial plastics. Controls received vehicle (distilled ethanol) at a dose equal to that used for the highest concentration of BPA. Mice were weighed weekly. Glucose tolerance tests were performed at nine weeks of age using a standard protocol for mice (jaxservices.jax.org). At 11 weeks of age, mice were fasted for five hours and sacrificed using $\mathrm{CO}_{2}$ asphyxiation and cervical dislocation. Perigonadal fat pads were dissected and weighed, and portions allocated for RNA extraction, histology, tissue metabolomics and adipokine measurements. Blood was collected to for measurement of serum insulin, glucose and adiponectin levels.

\section{RNA isolation}

Adipose tissue RNA was extracted using the RNeasy ${ }^{\text {Tix }}$ Lipid Tissue Mini Kit (Qiagen, Inc., Valencia, CA). RNA quality and concentration were assessed using an Experion RNA StdSens Chips on an Experion ${ }^{\text {stx }}$ automated electrophoresis system (Bio-Rad, Hercules, CA).

\section{Gene expression profiling}

Genome scale gene expression was performed on adipose tissue from male control and $500 \mathrm{nM}$ BPA mice in each strain $(n=6 /$ strain ${ }^{\star}$ treatment group). Total RNA (500 ng) was amplified, synthesized to cDNA, and hybridized to the MouseWG-6 v2 Expression BeadChip (Illumina, San Diego, CA). Expression profiling was conducted by the McGill University and Génome Québec Innovation Centre (Quebec, CA). Expression of leptin and the housekeeping gene hypoxanthine phosphoribosyl transferase (Hprt) was measured by quantitative realtime PCR (QPCR) using predesigned and validated primer sets and SYBRgreen chemistry (QuantiTect primers and SYBR Green PCR kit, Qiagen, Inc., Valencia, CA) on a CFX96 ${ }^{\mathrm{m}}$ Real-Time PCR Detection System (Bio-Rad, Hercules, CA). Relative gene expression was determined using the $\Delta \Delta \mathrm{Ct}$ method [36].

\section{Adipokine levels in adipose tissue}

Concentrations of leptin, resistin, interleukin 6 (IL-6), tumor necrosis factor alpha (TNFa), monocyte chemotactic protein 1 (MCP-1), and plasminogen activator inhibitor 1 (PAI-1) in adipose tissue homogenates were analyzed in duplicate by multiplexed flow cytometric assay using a mouse adipokine Milliplex map kit (MADPK$71 \mathrm{~K}$, Millipore, Billerica, MA) on a Luminex 200 system (Luminex Inc., Austin, TX). Adipokine protein levels were measured in $\mathrm{pg} / \mathrm{ml}$ and normalized to tissue protein, determined using a bicinchoninic acid assay (Thermo Scientific, Waltham, MA).

\section{Serum insulin, glucose and adiponectin levels}

Fasting serum insulin levels were measured using a commercially available ultra- sensitive mouse insulin ELISA kit (Crystal Chem Inc., Downers Grove, IL). Glucose was determined using a commercial colorimetric assay (Cayman Chemical, Ann Arbor, MI). Serum adiponectin levels were measured using a commercially available mouse adiponectin enzyme immunoassay kit (SPI-bio Bertin Pharma, Montigny le Bretonneux, France).

\section{Histological analysis of adipocyte size}

Adipocyte size was determined by measuring the area of adipocytes in H\&E-stained sections of paraformaldehyde-fixed abdominal adipose tissue using ImageJ (NIH; rsbweb.nih.gov/ij/), as we have previously described [37]. Approximately 200 adipocytes per mouse were measured.

\section{Metabolomics}

Metabolite abundance was determined in snap-frozen samples ( $n=4 /$ strain $^{\star}$ treatment group) of abdominal adipose tissue, as previously described $[37,38]$. Only tissue from males (of both strains) was used for metabolomics. Briefly, samples were homogenized in cold methanol $\left(500 \mu \mathrm{L}\right.$ at $\left.-78^{\circ} \mathrm{C}\right)$ and internal standards, tris $(5 \mu \mathrm{L}$ of 4.7

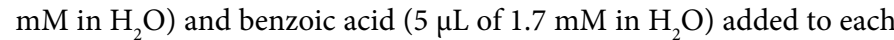
tube. Samples were extracted on ice, transferred to an autosampler vial, and analyzed by LC-MS/MS using selected reaction monitoring (SRM) in each of positive and negative ionization modes by known methods $(9,46)$. Raw files for each sample were first processed using mzRock (http://code.google.com/p/mzrock/), and Xcalibur Quan Browser (Thermo Scientific, Waltham, MA) was used to visualize and manually integrate metabolite peaks over a set time window.

\section{Statistical analysis}

Statistical analyses were performed in the language R. Effects 
Citation: Wyatt BS, Gooding JR, Das S, Campagna SR, Saxton AM, et al. (2016) Sex- and Strain-dependent Effects of Bisphenol: A Consumption in Juvenile Mice. J Diabetes Metab 7: 694. doi: 10.4172/2155-6156.1000694

of treatment, strain and treatment ${ }^{*}$ strain interactions in males and females on physiological parameters and QPCR data were determined using mixed models using 95\% confidence intervals, with significant F-tests followed by least squares means for post-hoc testing. Microarray data were analyzed in $\mathrm{R}$ using the Lumi package (Bioconductor.org), controlling false discovery rate using the q-value method of Storey [39]. Metabolomics data were corrected for normality using a logarithmic transformation and analyzed for main effects of treatment using ANOVA in R, controlling for effects of strain.

\section{Results}

\section{Effect of BPA on body weight and adiposity}

Bisphenol A was delivered at three fixed concentrations $(50 \mathrm{nM}$, $500 \mathrm{nM}$ and $5 \mu \mathrm{M})$ in drinking water to model repeated consumption due to daily food and beverage intake in children. These concentrations of BPA correspond to daily consumption levels of approximately $2.8,28$ and $280 \mu \mathrm{g} \mathrm{BPA} / \mathrm{kg}$ body weight, based on expected daily water intake of $0.2 \mathrm{ml} / \mathrm{g}$ body weight/day in mice (informatics.jax.org). This range of doses was chosen to span the EPA tolerable daily intake (TDI) level of $<50 \mu \mathrm{g} / \mathrm{kg}$ bw/day [40]. Strain and dose interacted to exert modest but statistically significant effects on final body weights, measured at 11 weeks of age, in males ( $p=0.025$; Figure $1 \mathrm{~A})$. The significant interaction was primarily due to differences in weights between the three levels of BPA treatment. For example, DBA/2J males in the $500 \mathrm{nM}$ group were significantly heavier than those in the $50 \mathrm{nM}$ and $5 \mu \mathrm{M}$ groups $(\mathrm{p}<0.05)$. Only the $50 \mathrm{nM}$ dose differed significantly from controls, and only in C57BL/6J. There was no significant effect of BPA on bodyweight in females of either strain (Figure 1B). Weight gain (11 week - 4 week body weight) was calculated to more specifically reflect the effects of BPA consumption in growth during the treatment period (Figures 1C and 1D). BPA did not alter weight gain in either sex ( $p>0.05)$. Food intake did not differ between groups (data not shown).

The weight of perigonadal fat pads was used to assess the specific effects of BPA on adipose accumulation during the treatment period. BPA consumption promoted fatness in male but not female mice. Both absolute fat pad weights (Figure 2A) and adiposity (fat pad weight/body weight; Figures $2 \mathrm{~B}$ and $2 \mathrm{C}$ ) were significantly increased by $\mathrm{BPA}$ in males $(\mathrm{p}=0.0095$ and $\mathrm{p}=0.0084$, respectively). This response was independent of strain ( $\mathrm{p}$-value $=0.83$, treatment ${ }^{\star}$ strain interaction), suggesting that obesogenic effects of BPA are robust to genetic background. The effect of BPA on adiposity was dosedependent, but not linear, consistent with nonmomotic effects of BPA that have been described for other phenotypes. In post-hoc analyses, only the $500 \mathrm{nM}$ BPA dose significantly increased fat pad weight ( $p=0.022$; Figure $2 \mathrm{~A}$ ) and adiposity ( $\mathrm{p}=0.036$; Figure $2 \mathrm{C})$. On average, male mice consuming the $500 \mathrm{nM}$ dose of BPA were $16.4 \%$ fatter than controls. Males in the $500 \mathrm{nM}$ treatment group were also significantly fatter than those consuming both the lowest $(p=0.0008)$ and highest BPA doses ( $p=0.022$; Figure $2 C$ ). In contrast, BPA did not alter absolute fat pad weight or adiposity in females (Figures $2 \mathrm{~B}$ and $2 \mathrm{D}$ ). Adipocyte size was measured in the male control and $500 \mathrm{nM}$ treatment groups to determine if BPA increased fatness by adipocyte hypertrophy (Figure 3). Adipocytes from DBA/2J males were larger than those from $\mathrm{C} 57 \mathrm{BL} / 6 \mathrm{~J}$ males $(\mathrm{p}=0.034)$, as expected due to increased adiposity in DBA/2J vs. C57BL/6J males ( $\mathrm{p}=1.4^{\star} 10$ 5). BPA consumption significantly increased adipocyte size in both C57BL/6J and DBA/2J mice relative to controls $(\mathrm{p}=0.0047)$, with no significant interactive effects between strain and treatment $(\mathrm{p}>0.05)$.

\section{Serum insulin, glucose, and glucose tolerance tests}

Circulating glucose and insulin levels and glucose tolerance

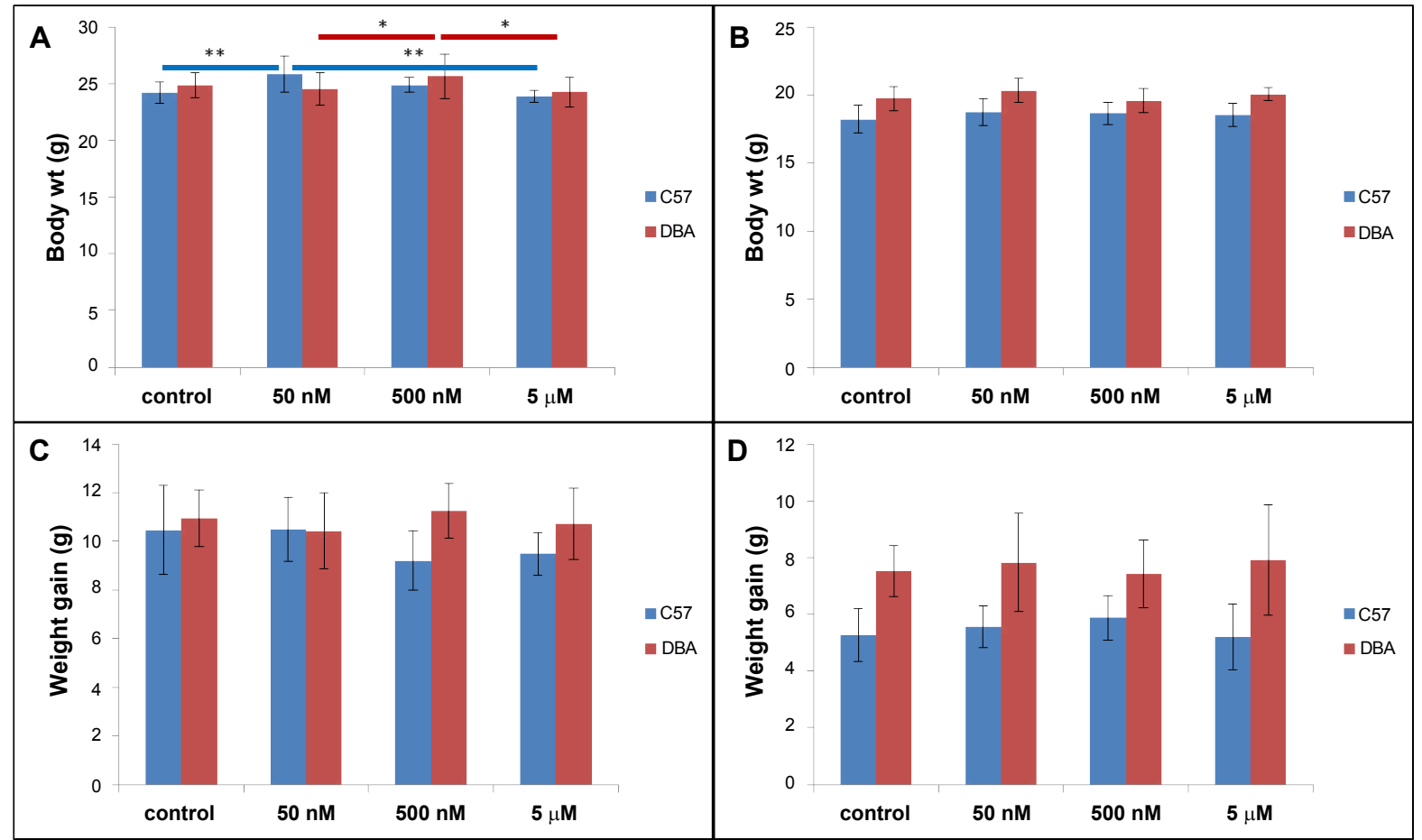

Figure 1: Effects of BPA on bodyweight $(A, B)$ and weight gain $(C, D)$. (A,C) males; $(B, D)$ females; means +/- std. dev; $n=8 /$ sex*strain*treatment group; $(A, B)$ body wt. at 11 weeks; $(C, D)$ Weight gain = body wt at 11 weeks - body wt. at 4 weeks; $(A)$. Red (DBA/2J) and blue (C57BL/6J) bars designate post-hoc tests for significant treatment effects within strain; $\left(^{*}\right) p<0.05,\left({ }^{* *}\right) p<0.01$. 
Citation: Wyatt BS, Gooding JR, Das S, Campagna SR, Saxton AM, et al. (2016) Sex- and Strain-dependent Effects of Bisphenol: A Consumption in Juvenile Mice. J Diabetes Metab 7: 694. doi: 10.4172/2155-6156.1000694
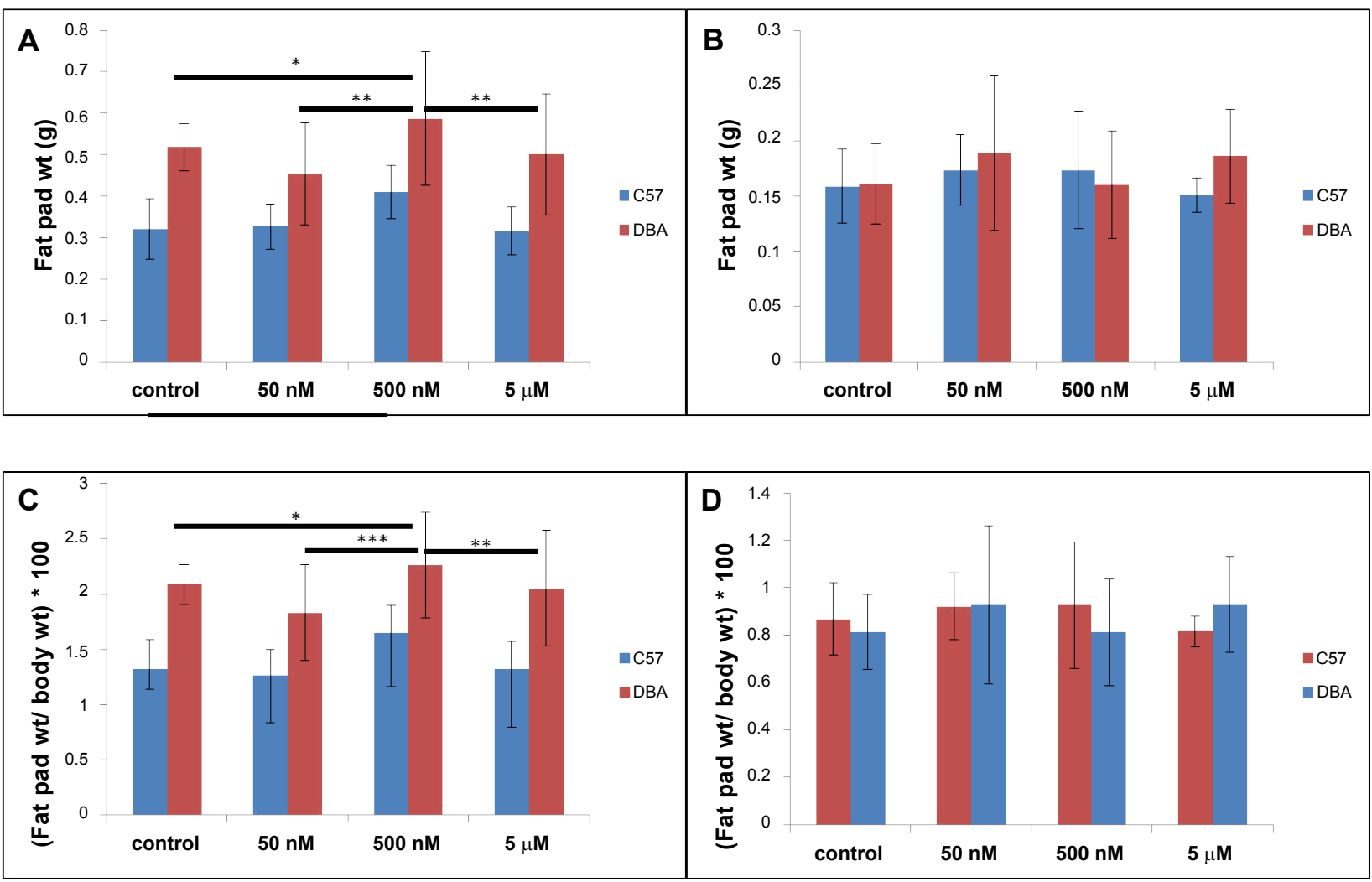

Figure 2: Effects of BPA on fat pad weight $(A, B)$ and adiposity $(C, D)$. (A,C) males; $(B, D)$ females; means $+/$ - std. dev., $n=8 /$ sex $^{*}$ strain*treatment group; $(A, C)$. Black bars $(A, C)$ designate post-hoc comparisons between pairs of treatments, $,\left(^{*}\right) p<0.05,\left({ }^{* *}\right) p<0.01,\left({ }^{* * *}\right) p<0.005 .\left({ }^{*}\right) p<0.05$.

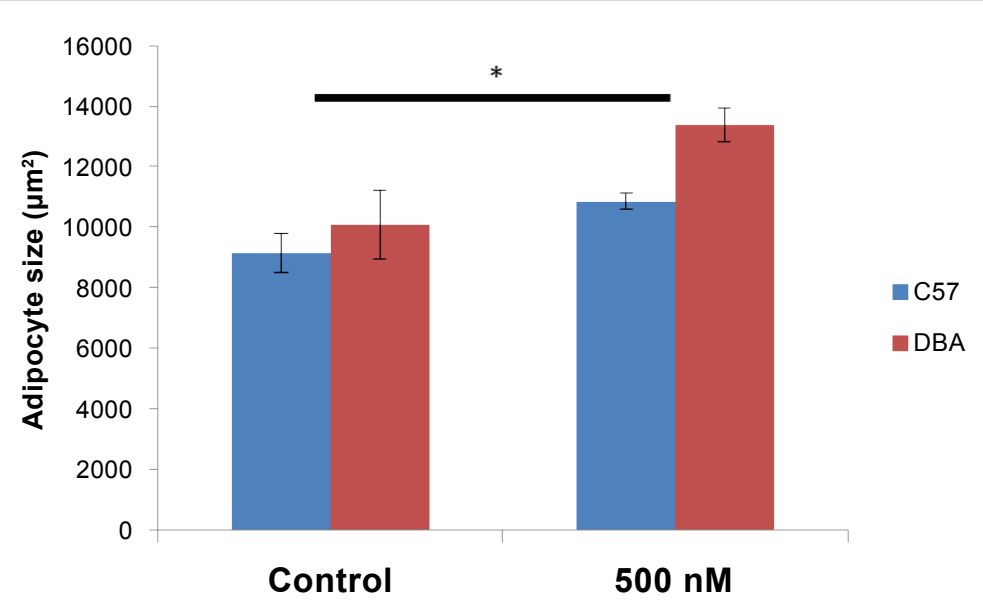

Figure 3: Effects of BPA on adipocyte area in male mice treated with $500 \mathrm{nM} \mathrm{BPA}$; means + - std. dev.; $n=4 /$ strain $^{*}$ treatment group. $\left({ }^{*}\right) p<0.05$, effect of $500 \mathrm{nM}$ BPA vs. control.

tests were used to determine if BPA consumption altered glucose metabolism, based on associations between urinary BPA levels risk factors for diabetes in various human studies [10,13,17,40-42]. Fasting serum glucose level was significantly lower in DBA/2J than C57BL/6J mice for both males $(p=0.0020$; Figure $4 A)$ and females $(p=0.0004$; Figure $4 \mathrm{~B}$ ), but BPA did not alter glycemia in mice of either sex. However, BPA exerted complex strain and sex-specific effects on serum insulin levels. While there was no effect of BPA on insulin in males (Figure 4C), BPA and strain interacted to control insulin level in females ( $p=8.75^{\star}$ E-06; Figure 4D). BPA increased insulin in C57BL/6J females, with significant differences between controls and the $50 \mathrm{nM}$ and $5 \mu \mathrm{M}$ treatment groups ( $\mathrm{p}=0.05$ and $\mathrm{p}=0.00016$, respectively). By contrast, each level of BPA treatment significantly decreased plasma insulin levels $(\mathrm{p}<0.001)$ in DBA/2J females relative to controls (Figure $4 \mathrm{D})$. Glucose tolerance tests were performed to determine if BPA consumption in juvenile mice altered glucose disposal. Area under the curve (AUC) was analyzed for effects of strain, BPA, and strain ${ }^{\star} \mathrm{BPA}$ interactions in males and females. As expected, glucose tolerance 


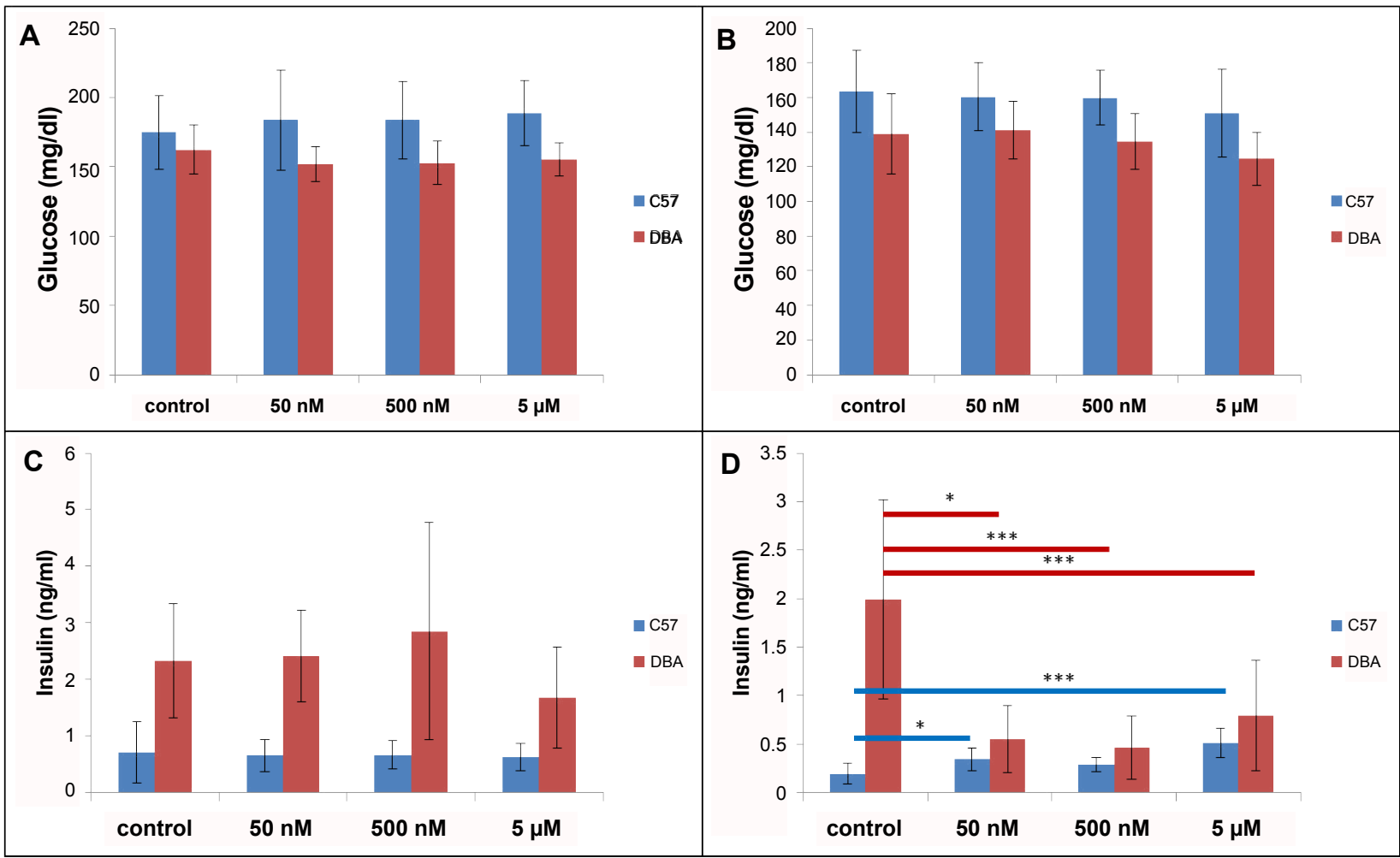

Figure 4: Effects of BPA on fasting serum glucose $(A, B)$ and insulin $(C, D)$ levels. $(A, C)$ males; $(B, D)$ females. Mice were fasted for five hours prior to blood collection; means $+/$ - std. dev., $n=6 /$ sex*$^{*}$ strain*treatment group;(D)red (DBA/2J) and blue (C57BL/6J) bars designate post-hoc comparisons between pairs of treatments within strain $\left(^{*}\right) p<0.05,\left({ }^{* *}\right) p<0.005$. Statistical differences between strains are not indicated on the graphs.

differed between strains in both males $\left(\mathrm{p}=2.1^{\star} 10-5\right)$ and females $\left(\mathrm{p}=6.4^{\star} 10-8\right)$ due to relatively high serum insulin levels and low blood glucose levels in DBA/2J mice [43]. However, BPA did not significantly affect glucose tolerance in males or females, or in either strain of mice. The results of glucose tolerance tests for C57BL/6J mice are shown in Figures $5 \mathrm{~A}$ and $5 \mathrm{~B}$, males; $5 \mathrm{C}$ and $5 \mathrm{D}$, females. Serum adiponectin, an adipokine that promotes insulin sensitivity, was measured in a limited set of samples (control and $500 \mathrm{nM}$ BPA), and only in males, based on reports suggesting that BPA suppresses adiponectin levels. Strain and BPA interacted to control circulating adiponectin $(p=0.045$; Figure 6). BPA significantly suppressed adiponectin level in C57BL/6 J males $(\mathrm{p}=0.00018)$ but not DBA/2J males. Baseline adiponectin levels also differed between the two strains, with lover levels in DBA/2J males $(\mathrm{p}=0.0004)$.

\section{Adipose adipokine profiles of BPA treated mice}

Adipose tissue levels of the adipokines PAI-1, MCP-1, resistin and leptin differed significantly between C57BL/6J and DBA/2J males (Table 1). In females, both MCP-1 and leptin were affected by strain, but none of the adipokines measured were affected significantly by BPA. In males, BPA consumption increased tissue leptin content, although the effect ( $\mathrm{p}=0.059)$ was not significant at the $\mathrm{p}<0.05$ level. Tissue PAI1 levels in males were affected by BPA in a strain-dependent manner $\left(\mathrm{p}=0.040\right.$, strain ${ }^{\star}$ treatment interaction). PAI- 1 content was increased in C57BL/6J males consuming both the $50 \mathrm{nM}$ and $500 \mathrm{nM}$ doses relative to controls $(\mathrm{p}=0.024$ and $\mathrm{p}=0.042$, respectively). There were no effects of BPA on PAI-I levels between any levels of BPA vs. control in DBA/2J males.

\section{Gene expression profiling and QPCR}

To identify changes in gene expression associated with the increased adiposity, global gene expression profiling was performed in adipose tissue from male C57BL/6J and DBA/2J mice in the control and $500 \mathrm{nM}$ BPA treatment groups. Data were analyzed using an ANOVA model that accounted for main effects of strain and BPA; and that included a strain ${ }^{\star} B P A$ interaction term to identify strainspecific responses. After controlling for false discovery (5\%) using q-value [39], 2366 genes differed between the two strains regardless of treatment $(\mathrm{FDR}<0.05)$. A total of 10 transcripts, two of which are transcript isoforms of the same gene (Neuroepithelial transforming gene 1 (Net1)), were significantly altered by BPA across strains, based on a main effect of treatment (Table 2). Of these, six genes were upregulated and four downregulated by BPA consumption. No genes were significantly influenced by interactions between strain and BPA exposure. Consistent with the effects of BPA on adipocyte size, leptin was upregulated by BPA treatment ( 1.44-fold), although the difference did not reach statistical significance. Leptin expression was also determined by QPCR, which indicated a statistically significant effect of $500 \mathrm{nM}$ BPA (1.4 fold-change, BPA vs. controls, $\mathrm{p}=0.015$ ).

\section{Metabolomics}

Adipose tissue metabolomics data were analyzed for a main effect of BPA in males because adiposity was only affected in males. No metabolites showed evidence of strain ${ }^{\star}$ treatment interactions $(p>0.05)$. BPA significantly altered the adipose tissue content of six metabolites across the two strains $(\mathrm{p}<0.05)$, with suggestive effects $(\mathrm{p}<0.10)$ on three additional compounds (Table 3). Included among this group 


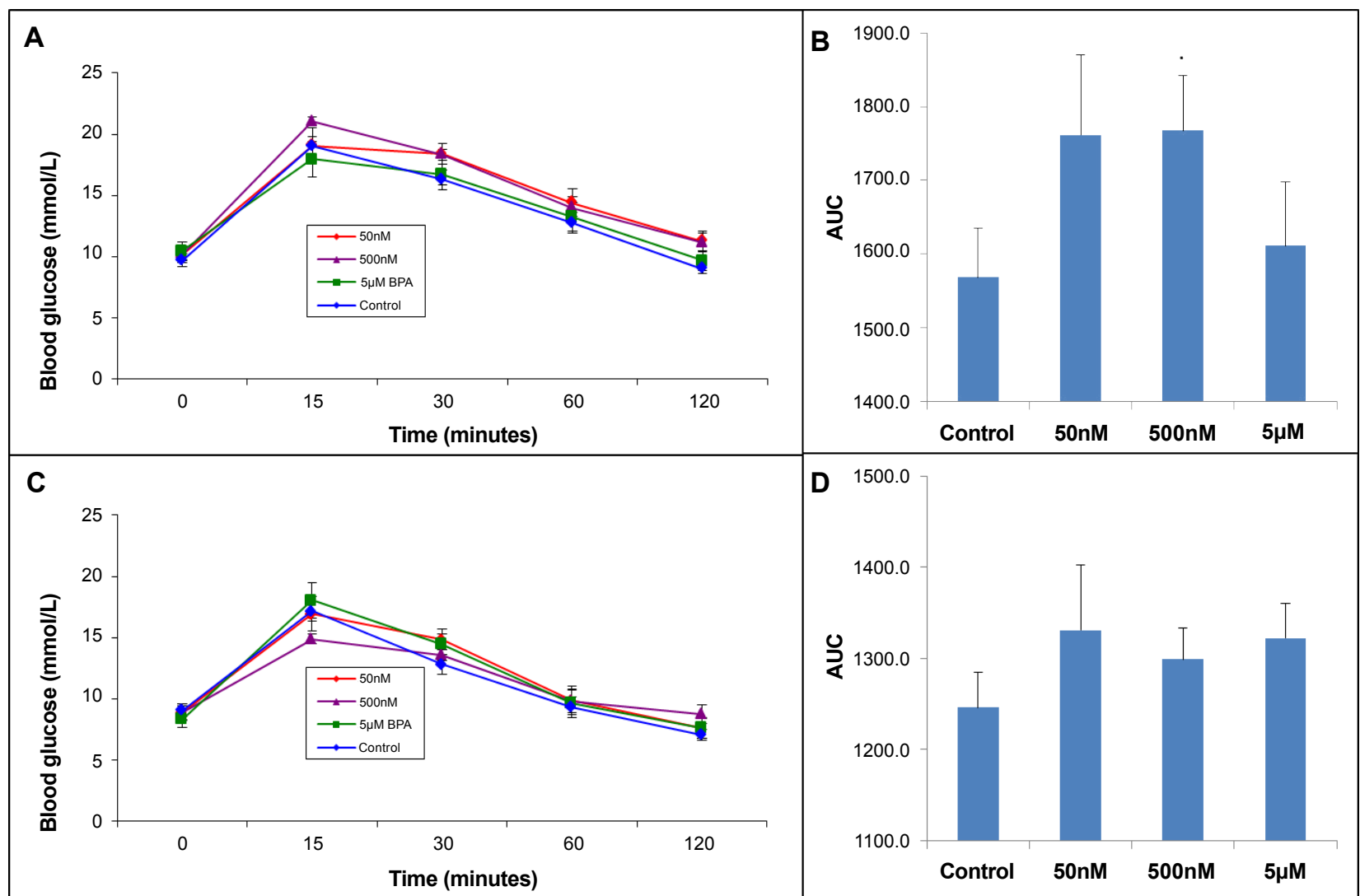

Figure 5: Effects of BPA on glucose tolerance in C57BL/6 mice $(A, B)$, males; $(C, D)$ females; $(A, C)$, time course of glucose disposal; (B,D), area under curve (AUC) based on $(A, C)$; means $+/$ - std. dev.; $n=6 /$ sex*treatment group.

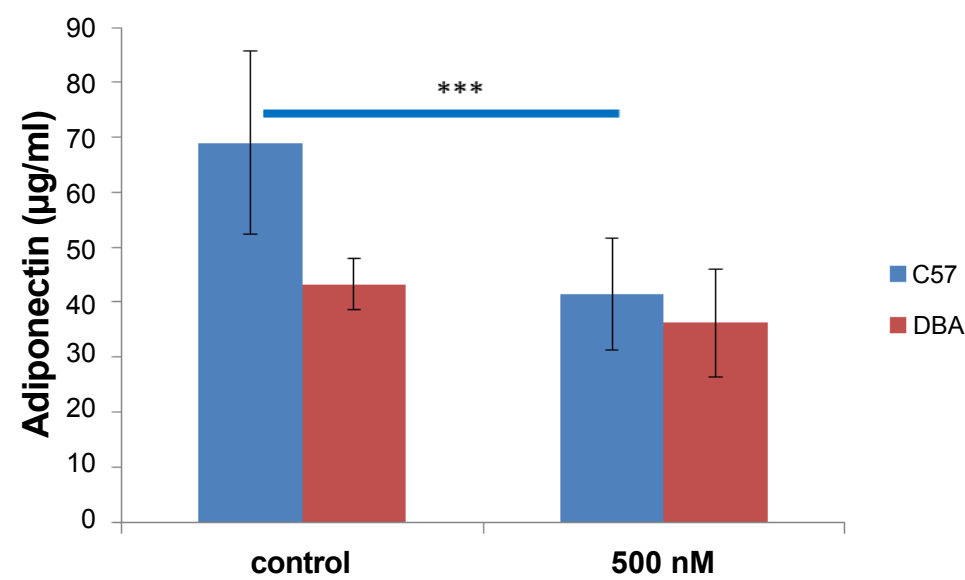

Figure 6: Effects of BPA on serum adiponectin level in male mice treated with $500 \mathrm{nM} \mathrm{BPA}$; means $+/-$ std. dev.; $\mathrm{n}=4 /$ strain*treatment group. $\left({ }^{* \star *}\right) \mathrm{p}<0.005$, main effect of 500 nM BPA vs. control.

are metabolites (citrate, isocitrate, fructose-6-phosphate, glucose-6phosphate and phosphoenolpyruvate) that suggest effects of BPA on intermediary glucose metabolism (Figure 7). Only N-acetyl-gluatmate, phosphoenolpyruvate and thymine levels showed monotonic responses to BPA. The dose of BPA $(500 \mathrm{nM})$ that increased adiposity relative to controls (Figure 2) also significantly increased phosphoenolpyruvate levels (1.51-fold) while decreasing isocitrate (0.75-fold) and citrate (0.50-fold) levels, suggesting effects of BPA on TCA cycle metabolism.
Tissue levels of AMP, ornithine, $\mathrm{N}$-acetylglutamate and thymine were also significantly affected by BPA consumption (Table 3 ).

\section{Discussion}

Most studies into BPA's potential as an obesogen have focused on effects of BPA transmitted in utero or perinatally through maternal circulation or lactation. We modeled BPA consumption in children BPA by adding the compound to drinking water of juvenile mice. 
Citation: Wyatt BS, Gooding JR, Das S, Campagna SR, Saxton AM, et al. (2016) Sex- and Strain-dependent Effects of Bisphenol: A Consumption in Juvenile Mice. J Diabetes Metab 7: 694. doi: 10.4172/2155-6156.1000694

Page 7 of 10

\begin{tabular}{|c|c|c|c|c|c|c|c|c|c|c|c|c|c|}
\hline & & \multicolumn{2}{|c|}{ Leptin } & \multicolumn{2}{|c|}{ Resistin } & \multicolumn{2}{|c|}{ MCP1 } & \multicolumn{2}{|c|}{ IL6 } & \multicolumn{2}{|c|}{ Tnfa } & \multicolumn{2}{|c|}{ PAl1 } \\
\hline \multicolumn{2}{|c|}{ Males } & Avg. ${ }^{a}$ & $S^{b}$ & Avg. & SD & Avg. & SD & Avg. & SD & Avg. & SD & Avg. & SD \\
\hline & & \multicolumn{2}{|c|}{$\begin{array}{l}\mathrm{p}_{\mathrm{TRT}}{ }^{\mathrm{c}}=0.059 \\
\mathrm{p}_{\mathrm{STR}}=0.021\end{array}$} & \multicolumn{2}{|c|}{$\begin{aligned} \mathrm{p}_{\mathrm{TRT}} & =0.687 \\
\mathrm{p}_{\mathrm{STR}} & =0.0086\end{aligned}$} & \multicolumn{2}{|c|}{$\begin{array}{l}\mathrm{p}_{\mathrm{TRT}}=0.0 .126 \\
\mathrm{p}_{\mathrm{STR}}=0.00047\end{array}$} & \multicolumn{2}{|c|}{$\begin{array}{l}\mathrm{p}_{\mathrm{TRT}}=0.994 \\
\mathrm{p}_{\mathrm{STR}}=0.289\end{array}$} & \multicolumn{2}{|c|}{$\begin{array}{c}\mathrm{p}_{\mathrm{TRT}}=0.73 \\
\mathrm{p}_{\mathrm{STR}}=\end{array}$} & \multicolumn{2}{|c|}{$\begin{array}{l}\mathrm{p}_{\mathrm{TRT}}=0.0261 \\
\mathrm{p}_{\mathrm{STR}}=0.00296\end{array}$} \\
\hline Strain & Treatment & & & & & & & & & & & & \\
\hline \multirow[t]{4}{*}{ C57 } & Cont. & 2.16 & 0.92 & 18.52 & 5.57 & 0.033 & 0.010 & 0.070 & 0.029 & 0.025 & 0.008 & 0.110 & 0.030 \\
\hline & $50 \mathrm{nM}$ & 2.17 & 0.71 & 17.16 & 1.90 & 0.036 & 0.009 & 0.077 & 0.021 & 0.028 & 0.004 & 0.202 & 0.093 \\
\hline & $500 \mathrm{nM}$ & 2.75 & 1.13 & 15.97 & 1.20 & 0.042 & 0.012 & 0.064 & 0.023 & 0.024 & 0.006 & 0.182 & 0.065 \\
\hline & $5 \mu \mathrm{M}$ & 1.82 & 0.35 & 17.86 & 2.77 & 0.036 & 0.016 & 0.066 & 0.013 & 0.024 & 0.005 & 0.132 & 0.062 \\
\hline \multirow[t]{4}{*}{ DBA } & Cont. & 2.89 & 0.73 & 17.11 & 1.63 & 0.052 & 0.025 & 0.069 & 0.034 & 0.025 & 0.009 & 0.109 & 0.037 \\
\hline & $50 \mathrm{nM}$ & 2.76 & 0.63 & 18.59 & 3.51 & 0.074 & 0.040 & 0.064 & 0.011 & 0.025 & 0.007 & 0.126 & 0.032 \\
\hline & $500 \mathrm{nM}$ & 3.31 & 0.81 & 17.11 & 2.27 & 0.072 & 0.038 & 0.065 & 0.011 & 0.024 & 0.006 & 0.121 & 0.030 \\
\hline & $5 \mu \mathrm{M}$ & 2.96 & 1.19 & 18.39 & 2.36 & 0.053 & 0.017 & 0.071 & 0.014 & 0.026 & 0.006 & 0.129 & 0.039 \\
\hline \multicolumn{14}{|c|}{ Females } \\
\hline Strain & Treatment & \multicolumn{2}{|c|}{$\begin{array}{l}\mathrm{p}_{\mathrm{TRT}}=0.207 \\
\mathrm{p}_{\mathrm{STR}}=0.035\end{array}$} & \multicolumn{2}{|c|}{$\begin{array}{l}\mathrm{p}_{\mathrm{TRT}}=0.940 \\
\mathrm{p}_{\mathrm{STR}}=0.718\end{array}$} & \multicolumn{2}{|c|}{$\begin{array}{c}\mathrm{p}_{\mathrm{TRT}}=0.54 \\
\mathrm{p}_{\mathrm{STR}}=0.00012\end{array}$} & \multicolumn{2}{|c|}{$\begin{array}{l}\mathrm{p}_{\mathrm{TRT}}=0.621 \\
\mathrm{p}_{\mathrm{STR}}=0.203\end{array}$} & \multicolumn{2}{|c|}{$\begin{array}{l}p_{\text {TRT }}=0.457 \\
p_{S T R}=0.541\end{array}$} & \multicolumn{2}{|c|}{$\begin{array}{l}p_{\text {TRT }}=0.265 \\
p_{S T R}=0.539\end{array}$} \\
\hline \multirow[t]{4}{*}{ C57 } & Cont. & 1.16 & 0.23 & 18.10 & 2.34 & 0.025 & 0.003 & 0.143 & 0.105 & 0.035 & 0.005 & 0.126 & 0.053 \\
\hline & $50 \mathrm{nM}$ & 1.10 & 0.29 & 17.81 & 1.48 & 0.032 & 0.007 & 0.182 & 0.078 & 0.039 & 0.005 & 0.097 & 0.024 \\
\hline & $500 \mathrm{nM}$ & 0.96 & 0.22 & 19.63 & 3.71 & 0.030 & 0.006 & 0.186 & 0.073 & 0.040 & 0.016 & 0.109 & 0.030 \\
\hline & $5 \mu \mathrm{M}$ & 1.08 & 0.25 & 17.96 & 2.43 & 0.029 & 0.007 & 0.153 & 0.059 & 0.037 & 0.009 & 0.091 & 0.034 \\
\hline \multirow[t]{4}{*}{ DBA } & Cont. & 1.37 & 0.73 & 18.99 & 3.01 & 0.058 & 0.038 & 0.110 & 0.042 & 0.034 & 0.012 & 0.109 & 0.054 \\
\hline & $50 \mathrm{nM}$ & 1.26 & 0.28 & 16.92 & 2.93 & 0.053 & 0.013 & 0.121 & 0.042 & 0.035 & 0.009 & 0.104 & 0.033 \\
\hline & $500 \mathrm{nM}$ & 1.09 & 0.31 & 18.40 & 2.81 & 0.041 & 0.010 & 0.164 & 0.193 & 0.035 & 0.007 & 0.077 & 0.017 \\
\hline & $5 \mu \mathrm{M}$ & 1.57 & 0.76 & 18.19 & 2.01 & 0.050 & 0.028 & 0.143 & 0.087 & 0.037 & 0.016 & 0.092 & 0.021 \\
\hline
\end{tabular}

a Data expressed as $\mathrm{pg} / \mathrm{mg}$ protein

${ }^{\mathrm{b}} \mathrm{SD}$, standard deviation

${ }^{c} p_{T R T}--p$-value for main effect of treatment

${ }^{d} p_{\text {STR }}-p$-value for main effect of treatment

Table 1: Effect of BPA on adipose tissue adipokine content

\begin{tabular}{|l|c|c|}
\hline \multicolumn{1}{|c|}{ Gene name } & Gene symbol & Fold change $^{\mathbf{a}}$ \\
\hline Calcium/calmodulin-dependent protein kinase & Camk1 & 1.22 \\
\hline (Heparan sulfate proteoglycan 2 & Hspg2 & 1.27 \\
\hline Neuroepithelial cell transforming 1 & Net1 (NM_001047159.1) & 0.00007 \\
\hline RUN and SH3 domain containing 2 & Rusc2 & 0.00012 \\
\hline Reticulon 2 & Rtn2 & 1.20 \\
\hline Neuroepithelial cell transforming 1 & Net1 (NM_019671.2) & 1.31 \\
\hline Family with sequence similarity 207, member A & Fam207a & 0.00013 \\
\hline & 4631423B10Rik & 0.00014 \\
\hline Cytochrome P450, family 2, subfamily f, polypeptide 2 & Cyp2f2 & 0.00021 \\
\hline GATS protein-like 3 & Gats/3 & 0.00031 \\
\hline
\end{tabular}

a500 nM BPA vs. control

${ }^{\mathrm{b}}$ raw $\mathrm{p}$-values corresponding to q-value $<0.05$

Table 2: Effects of BPA on gene expression.

Using this model, we found that consumption that approximates the EPA tolerable daily intake (TDI) level of $<50 \mu \mathrm{g} / \mathrm{kg}$ bw/day [44] significantly increases adiposity. We controlled exogenous sources of BPA by housing mice in cages made of BPA-free plastic, using glass water bottles, distilling ethanol used to solubilize BPA in glass tubing, and feeding a purified diet that lacks plant-based phytoestrogens; the primary source of BPA was drinking water. In contrast, children are exposed through a variety of routes associated with both the foodstream and consumer plastics. Therefore a level of BPA exposure sufficient to promote fatness in children could be reached through cumulative effects of the environment, even if contribution from any single source is less than what we provided in drinking water.

Epidemiological data link BPA to risk of obesity and Type 2 diabetes in humans, both of which are strongly influenced by interactions between genetic variation, gender and the environment
[12-14]. A growing body of literature in humans and rodents supports obesogenic and diabetogenic effects of BPA, but to our knowledge the question of genetic susceptibility to BPA exposure has not been addressed previously. The two inbred mouse strains we used represent many individuals in the U.S. population in that they are neither overtly obese and diabetic nor resistant to these diseases [34,45]. Based on this model, our data suggest broad sensitivity to the obesogenic actions of BPA, at least in males. In contrast, effects of BPA on insulinemia diverged between the two strains of mice, and were limited to females. Unlike genetic susceptibility, sex-specific effects of BPA have been described for a variety of traits, which has been attributed to its interactions with estrogen receptors. BPA may elicit different effects in males and females due to gender-specific expression patterns of estrogen receptors with which it can interact [33]. BPA itself can alter those expression patterns, further creating a basis for sex specific effects 
Citation: Wyatt BS, Gooding JR, Das S, Campagna SR, Saxton AM, et al. (2016) Sex- and Strain-dependent Effects of Bisphenol: A Consumption in Juvenile Mice. J Diabetes Metab 7: 694. doi: 10.4172/2155-6156.1000694

\begin{tabular}{|c|c|c|c|}
\hline Metabolite & Treatment & Fold-changea & P-value (ANOVA) \\
\hline \multirow[t]{4}{*}{ AMP } & & & 0.021 \\
\hline & $50 \mathrm{~nm}$ & 0.27 & \\
\hline & $500 \mathrm{~nm}$ & 0.99 & \\
\hline & $5 \mu \mathrm{M}$ & 2.00 & \\
\hline \multirow[t]{4}{*}{ Citrate } & & & 0.054 \\
\hline & $50 \mathrm{~nm}$ & 0.47 & \\
\hline & $500 \mathrm{~nm}$ & 0.50 & \\
\hline & $5 \mu \mathrm{M}$ & 1.12 & \\
\hline \multirow[t]{4}{*}{ Fructose-6-phosphate } & & & 0.091 \\
\hline & $50 \mathrm{~nm}$ & 0.43 & \\
\hline & $500 \mathrm{~nm}$ & 0.45 & \\
\hline & $5 \mu \mathrm{M}$ & 1.11 & \\
\hline \multirow[t]{4}{*}{ Glucose-6-phosphate } & & & 0.089 \\
\hline & $50 \mathrm{~nm}$ & 0.99 & \\
\hline & $500 \mathrm{~nm}$ & 1.01 & \\
\hline & $5 \mu \mathrm{M}$ & 0.97 & \\
\hline \multirow[t]{4}{*}{ Isocitrate } & & & 0.039 \\
\hline & $50 \mathrm{~nm}$ & 0.86 & \\
\hline & $500 \mathrm{~nm}$ & 0.75 & \\
\hline & $5 \mu \mathrm{M}$ & 1.01 & \\
\hline \multirow[t]{4}{*}{$\mathrm{N}$-acetyl-glutamate } & & & 0.017 \\
\hline & $50 \mathrm{~nm}$ & 1.67 & \\
\hline & $500 \mathrm{~nm}$ & 0.95 & \\
\hline & $5 \mu \mathrm{M}$ & 0.88 & \\
\hline \multirow[t]{4}{*}{ Ornithine } & & & 0.061 \\
\hline & $50 \mathrm{~nm}$ & 0.87 & \\
\hline & $500 \mathrm{~nm}$ & 1.38 & \\
\hline & $5 \mu \mathrm{M}$ & 1.34 & \\
\hline \multirow[t]{4}{*}{ Phosphoenolpyruvate } & & & 0.017 \\
\hline & $50 \mathrm{~nm}$ & 1.31 & \\
\hline & $500 \mathrm{~nm}$ & 1.51 & \\
\hline & $5 \mu \mathrm{M}$ & 1.88 & \\
\hline \multirow[t]{4}{*}{ Thymine } & & & 0.009 \\
\hline & $50 \mathrm{~nm}$ & 0.90 & \\
\hline & $500 \mathrm{~nm}$ & 0.77 & \\
\hline & $5 \mu \mathrm{M}$ & 0.49 & \\
\hline
\end{tabular}

aVS.control

Table 3: Effects of BPA on adipose tissue metabolites. of BPA exposure [46]. Less is known about genetic susceptibility to BPA's role in obesity and diabetes, although myriad pathways involved in these disorders are influenced by genetic variation in humans and in animal models. For example, pancreatic $\beta$-cells are a direct target of BPA actions [47-49], and numerous aspects of $\beta$-cell function differ between $\mathrm{C} 57 \mathrm{BL} / 6 \mathrm{~J}$ and $\mathrm{DBA} / 2 \mathrm{~J}$ mice $[34,47]$. It should be noted that there were no significant consequences for glucose tolerance within the window of BPA exposure used in this study, and whether the divergent effects on insulinemia would eventually impact glucose control requires further study. Nonetheless, our collective data suggest that susceptibility to obesogenic and diabetogenic effects of BPA is not hard-wired. Rather, within a population, individuals may be sensitive to some actions of BPA but not others, depending upon both genetic background and gender.

In addition to obesity and Type 2 diabetes, BPA is clinically associated with risk for coronary artery disease. This relationship appears in both cross-sectional and longitudinal studies, independent of traditional risk factors and with low levels of estimated BPA exposure $[17,41,42]$. Our data suggest that PAI-1, which was upregulated in males consuming BPA, may play a role in this relationship. PAI-1 is an adipokine that inhibits fibrinolysis $[50,51]$ and is elevated in obesity [52-54]. Elevated PAI-1 levels predispose individuals to atherosclerosis and myocardial infarction $[55,56]$. Whether increased adipose PAI1 content in our model was a direct response to BPA or an indirect consequence of fattening cannot be determined from our study. Given the associations between BPA exposure and atherosclerosis, the effect of BPA on PAI-1 warrants further study.

Adipose tissue may serve as an in vivo reservoir of BPA [57] which has direct effects on adipocytes [58]. Although the $500 \mathrm{nM}$ dose of BPA significantly increased adiposity and adipocyte size, the effects on adipose gene expression were relatively modest. This may be because the obesogenic response to BPA ( $\sim 16 \%$ increase in adiposity) was considerably less than for genetic mutations and high fat diet that can increase fatness by more than 3 -fold $[59,60]$. Nonetheless, the set of genes with expression altered by BPA consumption includes candidates that may inform mechanistic studies of BPA as an obesogen. BPA increased expression of heparan sulfate proteoglycan 2(Hspg2) and reticulon 2 (Rtn2). Hspg2 encodes a heparin sulfate proteoglycan

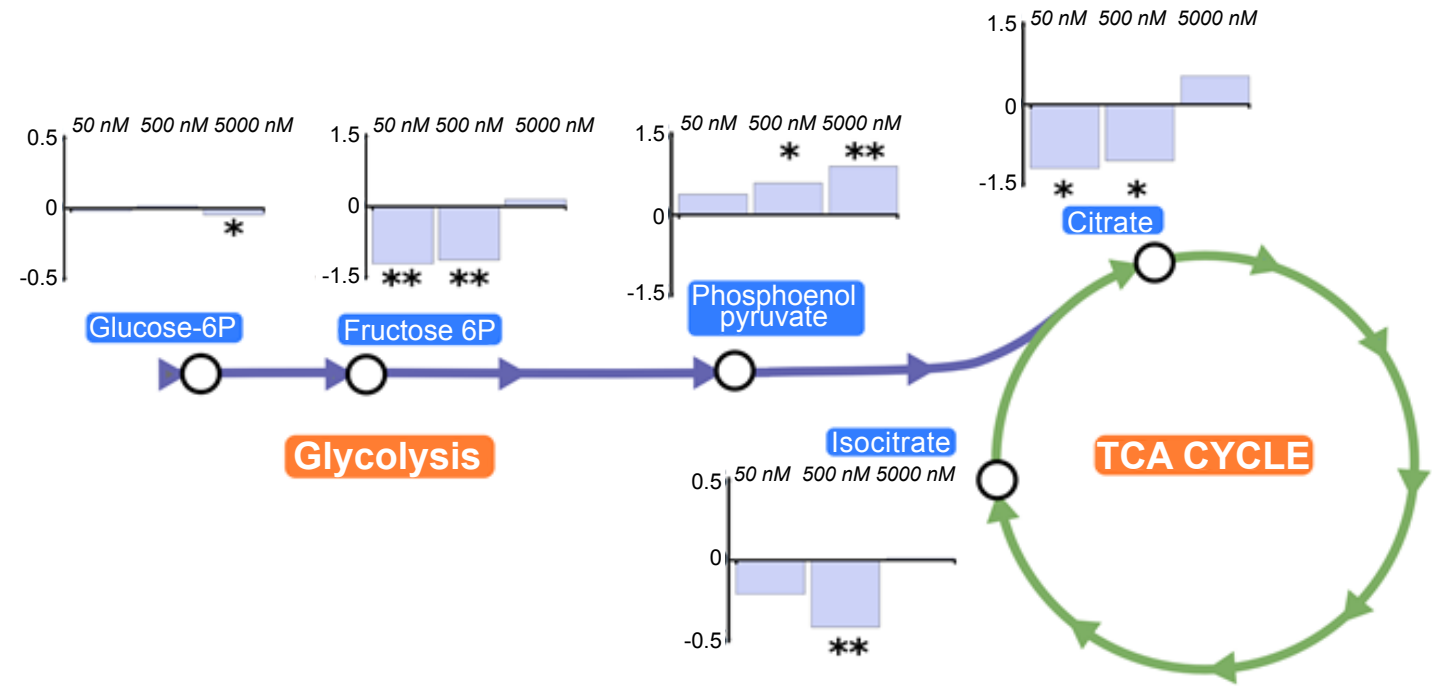

Figure 7: Effects of BPA on glycolytic and TCA cycle intermediates adipose tissue. Data for select metabolites from metabolomic analysis are represented and expressed as log2-fold-change relative to control. 
Citation: Wyatt BS, Gooding JR, Das S, Campagna SR, Saxton AM, et al. (2016) Sex- and Strain-dependent Effects of Bisphenol: A Consumption in Juvenile Mice. J Diabetes Metab 7: 694. doi: 10.4172/2155-6156.1000694

contained within the extracellular matrix (ECM) [61]. Enriching the ECM in Hspg2 has been shown to create a tissue microenvironment conducive to adipogenesis [62]. Rtn2 encodes a member of the reticulon family of proteins that are located primarily on the endoplasmic reticulum membrane where they regulate its structure and function [63]. Rtn2 plays an important role in translocation of GLUT4 to the cell membrane [64]. Increased expression with BPA exposure may therefore facilitate glucose uptake into adipocytes. As in mice made fattier by BPA consumption, Rtn2 expression is upregulated in adipose tissue of obese vs. lean humans and of diet-induced obese mice vs. controls [65]. BPA also upregulated expression of CaMKII, a calmodulin kinase family member CaMKII is upregulated by BPA in heart [66], brain [67], Sertoli cells [68], and endothelial cells [69], where it mediates the effects of BPA on oxidative stress. BPA promotes oxidative stress and impairs mitochondrial function in a number of tissues [70-72]. We did not assess mitochondrial function in our model, but it is possible that BPA consumption increased fatness by impairing mitochondrial metabolism. Consistent with this concept, Garcia-Arevalo et al. [73] recently reported that BPA exposure in utero increased adiposity and adipocyte size in adult mice ( 28 weeks of age) by down-regulating mitochondrial fatty acid oxidation. Changes in the adipose metabolome support an effect of BPA on metabolism. Significant effects on content of phosphoenolpyruvate, a substrate for glyceroneogenesis, as well as citrate, isocitrate and fructose-6-phosphate suggest that BPA may increase adipocyte triglyceride storage by shifting substrate metabolism to enhance the availability of glycerol for fatty acid (re)esterification and triacylglycerol synthesis. In combination, our molecular data suggest that BPA induces fatness through novel mechanisms relative to those characterized in established models of obesity.

Extrapolating to humans, our collective results suggest that BPA may contribute to the increasing incidence of obesity observed in children, both in the U.S. and globally. An expert panel recently estimated that prenatal BPA exposure would be likely to cause 42,000 new cases of childhood obesity in the European Union, with estimated lifetime costs of $€ 1.54$ billion due to associated health consequences [74]. Our results suggest that BPA consumption outside the pre-/perinatal window may further increase this risk. They also indicate that the obesogenic and diabetogenic effects of BPA can be uncoupled, and can manifest differently depending upon gender and genetic background. Given the prevalence and impact of childhood obesity on long term health, continued studies into the effects of BPA consumption in children are warranted.

\section{References}

1. Grün F, Blumberg B (2009) Endocrine disrupters as obesogens. Mol Cell Endocrinol 304: 19-29.

2. Grün F, Blumberg B (2009) Minireview: the case for obesogens. Mol Endocrinol 23: $1127-1134$

3. Grun F, Blumberg B (2007) Perturbed nuclear receptor signaling by environmental obesogens as emerging factors in the obesity crisis. Rev Endocr Metab Disord 8: 161-171.

4. Vom Saal FS, Nagel SC, Coe BL, Angle BM, Taylor JA (2012) The estrogenic endocrine disrupting chemical bisphenol A (BPA) and obesity. Mol Cell Endocrinol 354: 74-84.

5. Hoekstra EJ, Simoneau C (2013) Release of bisphenol A from polycarbonate: a review. Crit Rev Food Sci Nutr 53: 386-402.

6. Vandenberg LN, Hauser R, Marcus M, Olea N, Welshons WV (2007) Human exposure to bisphenol A (BPA). Reprod Toxicol 24: 139-177.

7. Geens T, Aerts D, Berthot C, Bourguignon JP, Goeyens L, et al. (2012) A review of dietary and non-dietary exposure to bisphenol-A. Food Chem Toxicol 50: $3725-3740$.
8. Calafat AM, Ye X, Wong LY, Reidy JA, Needham LL (2008) Exposure of the U.S. population to bisphenol A and 4-tertiary-octylphenol: 2003-2004. Environ Health Perspect 116: 39-44.

9. Song Y, Hauser R, Hu FB, Franke AA, Liu S, et al. (2014) Urinary concentrations of bisphenol $A$ and phthalate metabolites and weight change: a prospective investigation in US women. Int J Obes (Lond) 38: 1532-1537.

10. Shankar A, Teppala S (2012) Urinary bisphenol A and hypertension in a multiethnic sample of US adults. J Environ Public Health 2012: 481641.

11. Ko A, Hwang MS, Park JH, Kang HS, Lee HS, et al. (2014) Association between Urinary Bisphenol A and Waist Circumference in Korean Adults. Toxicol Res 30: $39-44$

12. Wang T, Li M, Chen B, Xu M, Xu Y, et al. (2012) Urinary bisphenol A (BPA) concentration associates with obesity and insulin resistance. J Clin Endocrino Metab 97: E223-227.

13. Shankar A, Teppala S (2011) Relationship between urinary bisphenol A levels and diabetes mellitus. J Clin Endocrinol Metab 96: 3822-3826.

14. Ahmadkhaniha R, Mansouri M, Yunesian M, Omidfar K, Jeddi MZ, et al. (2014) Association of urinary bisphenol a concentration with type-2 diabetes mellitus. J Environ Health Sci Eng 12: 64.

15. Posnack NG (2014) The adverse cardiac effects of Di (2-ethylhexyl)phthalate and Bisphenol A. Cardiovasc Toxicol 14: 339-357.

16. Shankar A, Teppala S, Sabanayagam C (2012) Bisphenol A and periphera arterial disease: results from the NHANES. Environ Health Perspect 120: $1297-$ 1300.

17. Lang IA, Galloway TS, Scarlett A, Henley WE, Depledge M, et al. (2008) Association of urinary bisphenol A concentration with medical disorders and laboratory abnormalities in adults. JAMA 300: 1303-1310.

18. Bearer CF (1995) How are children different from adults? Environ Health Perspect 103 Suppl 6: 7-12.

19. Becker K, Göen T, Seiwert M, Conrad A, Pick-Fuss H, et al. (2009) GerES IV: phthalate metabolites and bisphenol $A$ in urine of German children. Int $\mathrm{J}$ Hyg Environ Health 212: 685-692.

20. Teitelbaum SL (2008) Temporal variability in urinary concentrations of phthalate metabolites, phytoestrogens and phenols among minority children in the United States. Environ Res 106: 257-269.

21. Xue J (2015) Urinary levels of endocrine-disrupting chemicals, including bisphenols, bisphenol A diglycidyl ethers, benzophenones, parabens, and triclosan in obese and non-obese Indian children. Environ Res 137: 120-128.

22. Frederiksen H, Aksglaede L, Sorensen K, Nielsen O, Main KM, et al. (2013) Bisphenol $A$ and other phenols in urine from Danish children and adolescents analyzed by isotope diluted TurboFlow-LC-MS/MS. Int J Hyg Environ Health 216: $710-720$.

23. Eng DS, Lee JM, Gebremariam A, Meeker JD, Peterson K, et al. (2013) Bisphenol $A$ and chronic disease risk factors in US children. Pediatrics 132 e637-645.

24. Bhandari R, Xiao J, Shankar A (2013) Urinary bisphenol A and obesity in U.S children. Am J Epidemiol 177: 1263-1270.

25. Trasande L, Attina TM, Blustein J (2012) Association between urinary bispheno A concentration and obesity prevalence in children and adolescents. JAMA 308: 1113-1121.

26. Harley KG, Schall RA, Chevrier J, Tyler K, Aguirre H, et al. (2013) Prenata and postnatal bisphenol $A$ exposure and body mass index in childhood in the CHAMACOS cohort. Environ Health Perspect 121: 514-520.

27. Wilson NK (2007) An observational study of the potential exposures of preschool children to pentachlorophenol, bisphenol-A, and nonylphenol at home and daycare. Environ Res 103: 9-20.

28. Liao C, Kannan K (2013) Concentrations and profiles of bisphenol A and othe bisphenol analogues in foodstuffs from the United States and their implications for human exposure. J Agric Food Chem 61: 4655-4662.

29. Lakind JS, Naiman DQ (2011) Daily intake of bisphenol. A and potentia sources of exposure: 2005-2006 National Health and Nutrition Examination Survey. J Expo Sci Environ Epidemiol 21: 272-279.

30. Howdeshell KL, Hotchkiss AK, Thayer KA, Vandenbergh JG, vom Saal FS (1999) Exposure to bisphenol A advances puberty. Nature 401: 763-764. 
Citation: Wyatt BS, Gooding JR, Das S, Campagna SR, Saxton AM, et al. (2016) Sex- and Strain-dependent Effects of Bisphenol: A Consumption in Juvenile Mice. J Diabetes Metab 7: 694. doi: 10.4172/2155-6156.1000694

31. Howdeshell KL, Peterman PH, Judy BM, Taylor JA, Orazio CE, et al. (2003) Bisphenol $A$ is released from used polycarbonate animal cages into water at room temperature. Environ Health Perspect 111: 1180-1187.

32. Rubin BS, Murray MK, Damassa DA, King JC, Soto AM (2001) Perinatal exposure to low doses of bisphenol $A$ affects body weight, patterns of estrous cyclicity, and plasma LH levels. Environ Health Perspect 109: 675-680.

33. Alonso-Magdalena $P$, Ropero $A B$, Soriano S, García-Arévalo M, Ripoll C, et al. (2012) Bisphenol-A acts as a potent estrogen via non-classical estrogen triggered pathways. Mol Cell Endocrinol 355: 201-207.

34. Davis RC, van Nas A, Castellani LW, Zhao Y, Zhou Z, et al. (2012) Systems genetics of susceptibility to obesity-induced diabetes in mice. Physiol Genomics 44: $1-13$

35. Lynch, RM (2010) Identifying genetic loci and spleen gene coexpression networks underlying immunophenotypes in BXD recombinant inbred mice. Physiol Genomics 41: 244-253.

36. Livak KJ, Schmittgen TD (2001) Analysis of relative gene expression data using real-time quantitative PCR and the 2(-Delta Delta $\mathrm{C}(\mathrm{T})$ ) Method. Methods 25: 402-408.

37. Ji B (2014) Molecular and Metabolic Profiles Suggest That Increased Lipid Catabolism in Adipose Tissue Contributes to Leanness in Domestic Chickens. Physiol Genomics.

38. Ji B, Ernest B, Gooding JR, Das S, Saxton AM, et al. (2012) Transcriptomic and metabolomic profiling of chicken adipose tissue in response to insulin neutralization and fasting. BMC Genomics 13: 441

39. Storey JD, Tibshirani R (2003) Statistical significance for genomewide studies Proceedings of the National Academy of Sciences of the United States of America 100: 9440-9445.

40. Beydoun HA, Khanal S, Zonderman AB, Beydoun MA (2014) Sex differences in the association of urinary bisphenol-A concentration with selected indices of glucose homeostasis among U.S. adults. Ann Epidemiol 24: 90-97.

41. Melzer D, Gates P, Osborne NJ, Henley WE, Cipelli R, et al. (2012) Urinary bisphenol a concentration and angiography-defined coronary artery stenosis. PLoS One 7: e43378

42. Melzer D, Rice NE, Lewis C, Henley WE, Galloway TS (2010) Association of urinary bisphenol a concentration with heart disease: evidence from NHANES 2003/06. PLoS One 5: e8673.

43. Alexander J, Chang GQ, Dourmashkin JT, Leibowitz SF (2006) Distinct phenotypes of obesity-prone AKR/J, DBA2J and C57BL/6J mice compared to control strains. Int J Obes (Lond) 30: 50-59.

44. Agency U.S.E.P (2004) Bisphenol A. (CASRN 80-05-7).

45. Reed DR, Tordoff MG (2015) Survey of adipose depots, body size, and heart and kidney weights in males of 28 inbred strains of mice.

46. Cao J, Mickens JA, McCaffrey KA, Leyrer SM, Patisaul HB (2012) Neonata Bisphenol A exposure alters sexually dimorphic gene expression in the postnatal rat hypothalamus. Neurotoxicology 33: 23-36

47. Dokmanovic-Chouinard M, Chung WK, Chevre JC, Watson E, Yonan J, et al (2008) Positional cloning of "Lisch-Like", a candidate modifier of susceptibility to type 2 diabetes in mice. PLoS Genet 4: e1000137.

48. Fang F, Chen D, Yu P, Qian W, Zhou J, et al. (2015) Effects of Bisphenol A on glucose homeostasis and brain insulin signaling pathways in male mice. Gen Comp Endocrinol 212: 44-50.

49. Marmugi A (2012) Low doses of bisphenol A induce gene expression related to lipid synthesis and trigger triglyceride accumulation in adult mouse liver Hepatology 55: 395-407.

50. Strakovsky RS (2015) Developmental bisphenol A (BPA) exposure leads to sex-specific modification of hepatic gene expression and epigenome at birth that may exacerbate high-fat diet-induced hepatic steatosis. Toxicol Appl Pharmacol 284: 101-112.

51. Lijnen HR (2005) Pleiotropic functions of plasminogen activator inhibitor-1. J Thromb Haemost 3: 35-45

52. Shimomura I, Funahashi T, Takahashi M, Maeda K, Kotani K, et al. (1996) Enhanced expression of PAI-1 in visceral fat: possible contributor to vascular disease in obesity. Nat Med 2: 800-803.
53. Vague $P$, Juhan-Vague I, Chabert V, Alessi MC, Atlan C (1989) Fat distribution and plasminogen activator inhibitor activity in nondiabetic obese women. Metabolism 38: 913-915.

54. Juhan-Vague I, Alessi MC (1997) PAI-1, obesity, insulin resistance and risk of cardiovascular events. Thromb Haemost 78: 656-660.

55. Kohler HP, Grant PJ (2000) Plasminogen-activator inhibitor type 1 and coronary artery disease. N Engl J Med 342: 1792-1801.

56. Thogersen AM (1998) High plasminogen activator inhibitor and tissue plasminogen activator levels in plasma precede a first acute myocardial infarction in both men and women: evidence for the fibrinolytic system as an independent primary risk factor. Circulation 98: 2241-2247.

57. Wang L, Asimakopoulos AG, Kannan K (2015) Accumulation of 19 environmental phenolic and xenobiotic heterocyclic aromatic compounds in human adipose tissue. Environ Int 78: 45-50

58. Valentino R (2013) Bisphenol-A impairs insulin action and up-regulates inflammatory pathways in human subcutaneous adipocytes and 3T3-L1 cells. PLoS One 8: e82099.

59. Wang B, Chandrasekera PC, Pippin JJ (2014) Leptin- and leptin receptordeficient rodent models: relevance for human type 2 diabetes. Curr Diabetes Rev 10: 131-145.

60. West DB, Boozer CN, Moody DL, Atkinson RL (1992) Dietary obesity in nine inbred mouse strains. Am J Physiol 262: R1025-1032.

61. Farach-Carson MC (2014) Border patrol: insights into the unique role of perlecan/heparan sulfate proteoglycan 2 at cell and tissue borders. Matrix Biol 34: 64-79.

62. Ang XM (2014) Macromolecular crowding amplifies adipogenesis of human bone marrow-derived mesenchymal stem cells by enhancing the proadipogenic microenvironment. Tissue Eng Part A 2014. 20: 966-981.

63. Yang YS, Strittmatter SM (2007) The reticulons: a family of proteins with diverse functions. Genome Biol 8: 234.

64. Ikemoto T, Hosoya T, Takata K, Aoyama H, Hiramatsu T, et al. (2009) Functional role of neuroendocrine-specific protein-like 1 in membrane translocation of GLUT4. Diabetes 58: 2802-2812.

65. Diawara MR, Hue C, Wilder SP, Venteclef N, Aron-Wisnewsky J, et al. (2014) Adaptive expression of microRNA-125a in adipose tissue in response to obesity in mice and men. PLoS One 9: e91375.

66. Gao X (2013) Molecular mechanisms underlying the rapid arrhythmogenic action of bisphenol. A in female rat hearts. Endocrinology 154: 4607-4617.

67. Viberg H, Lee I (2012) A single exposure to bisphenol A alters the levels of important neuroproteins in adult male and female mice. Neurotoxicology 33 : 1390-1395.

68. Qian W, Zhu J, Mao C, Liu J, Wang Y, et al. (2014) Involvement of CaMCaMKII-ERK in bisphenol A-induced Sertoli cell apoptosis. Toxicology 324: $27-34$

69. Saura M, Marquez S, Reventun P, Olea-Herrero N, Arenas MI, et al. (2014) Ora administration of bisphenol $A$ induces high blood pressure through angiotensin II/CaMKII-dependent uncoupling of eNOS. FASEB J 28: 4719-4728.

70. Yang YJ, Hong YC, Oh SY, Park MS, Kim H, et al. (2009) Bisphenol A exposure is associated with oxidative stress and inflammation in postmenopausa women. Environ Res 109: 797-801.

71. Xia W, Jiang Y, Li Y, Wan Y, Liu J, et al. (2014) Early-life exposure to bispheno a induces liver injury in rats involvement of mitochondria-mediated apoptosis. PLos One 9: e90443.

72. Kaur K, Chauhan V, Gu F, Chauhan A (2014) Bisphenol A induces oxidative stress and mitochondrial dysfunction in lymphoblasts from children with autism and unaffected siblings. Free Radic Biol Med 76: 25-33.

73. García-Arevalo M, Alonso-Magdalena P, Rebelo Dos Santos J, Quesada I Carneiro EM, et al. (2014) Exposure to bisphenol-A during pregnancy partially mimics the effects of a high-fat diet altering glucose homeostasis and gene expression in adult male mice. PLoS One 9: e100214.

74. Legler J, Fletcher T, Govarts E, Porta M, Blumberg B, et al. (2015) Obesity, diabetes, and associated costs of exposure to endocrine-disrupting chemicals in the European Union. J Clin Endocrinol Metab 100: 1278-1288. 